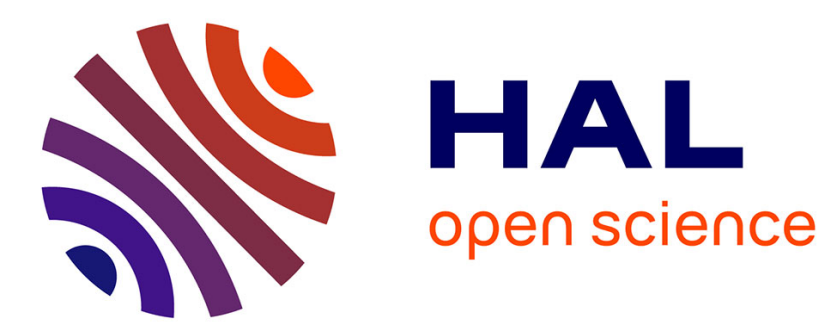

\title{
The Welfare Costs of Corruption
}

Heinz Welsch

\section{To cite this version:}

Heinz Welsch. The Welfare Costs of Corruption. Applied Economics, 2008, 40 (14), pp.1839-1849. 10.1080/00036840600905225 . hal-00582020

\section{HAL Id: hal-00582020 https://hal.science/hal-00582020}

Submitted on 1 Apr 2011

HAL is a multi-disciplinary open access archive for the deposit and dissemination of scientific research documents, whether they are published or not. The documents may come from teaching and research institutions in France or abroad, or from public or private research centers.
L'archive ouverte pluridisciplinaire HAL, est destinée au dépôt et à la diffusion de documents scientifiques de niveau recherche, publiés ou non, émanant des établissements d'enseignement et de recherche français ou étrangers, des laboratoires publics ou privés. 


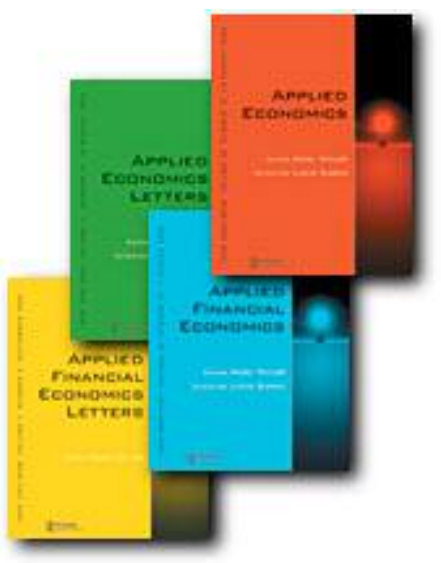

The Welfare Costs of Corruption

\begin{tabular}{|r|l|}
\hline Journal: & Applied Economics \\
\hline Manuscript ID: & APE-05-0658.R1 \\
\hline Journal Selection: & Applied Economics \\
\hline JEL Code: & $\begin{array}{l}\text { D61 - Allocative Efficiency|Cost Benefit Analysis < D6 - Welfare } \\
\text { Economics < D - Microeconomics, I31 - General Welfare|Basic } \\
<\text { I - Health, Education, and Welfare, D73 - Bureaucracy; Public } \\
\text { Admin. Processes; Corruption < D7 - Analysis of Collective } \\
\text { Decision-Making < D - Microeconomics }\end{array}$ \\
\hline Keywords: & corruption, welfare measurement, subjective well-being, happiness \\
\hline
\end{tabular}




\title{
The Welfare Costs of Corruption
}

\author{
Heinz Welsch \\ Department of Economics \\ University of Oldenburg \\ 26111 Oldenburg, Germany \\ welsch@uni-oldenburg.de \\ Revised Version \\ Previous Title: "How Corruption Affects Subjective Well-Being"
}

\begin{abstract}
Corruption has been shown to affect a variety of economic indicators, especially GDP per capita. However, as GDP is not a genuine indicator of welfare, it may reflect the welfare costs of corruption only in an incomplete way. This paper uses self-rated subjective well-being as an empirical approximation to general welfare and shows that cross-national welfare - operationalized in this way - is affected by corruption not only indirectly, through GDP, but also directly, through non-material factors. The paper estimates the size of these effects as well as their monetary equivalent. The direct effect - not previously investigated in the corruption literature - is found to be substantially larger than the indirect effect.
\end{abstract}

Running Title: Welfare Costs of Corruption

Keywords: corruption; welfare measurement; subjective well-being; happiness

JEL classification: D73, I31, D61

Acknowledgements: I am grateful to Udo Ebert, Klaus W. Schüler, an anonymous referee, and seminar participants at the University of Oldenburg for useful comments. 


\section{Introduction}

Corruption involves behavior on the part of public officials in which they unlawfully enrich themselves by the misuse of the power entrusted to them (Transparency International 2000). Levels of corruption have undergone considerable changes in recent years. While some countries succeeded in reducing corruption, others experienced an increase. In the period 2001-2004, for instance, Transparency International's 10-point Corruption Perceptions Index improved by as much as 1.1 points in the case of Bangladesh while deteriorating by no less than 1.3 points in the case of Namibia. ${ }^{1}$

What are the effects of changes in corruption, and how are they to be evaluated? Empirical research has shown that corruption affects a variety of economic indicators, such as government expenditures, total investment, capital flows and foreign direct investment, international trade, foreign aid, and GDP per capita (see Lambsdorff 1999 for an overview). Among these indicators, per capita GDP can be seen as a condensed measure that aggregates several of the economic effects of corruption. However, as GDP is hardly viewed as a genuine indicator of welfare, it probably reflects the welfare costs of corruption only in a crude and incomplete way.

This paper pursues a different approach to studying the welfare effects of corruption. Following a growing literature in economics (see Frey and Stutzer 2002), it uses self-rated subjective well-being ('happiness', life satisfaction) elicited in surveys as an empirical approximation to general welfare and explores several channels through which welfare operationalized in this way - is affected by corruption.

Since subjective well-being (SWB) prevailing in a country is linked to average income (Di Tella et al. 2003, Hagerty and Veenhoven 2003), one channel through which corruption affects SWB involves corruption's effect on per capita GDP. In addition to this indirect effect, however, corruption may affect SWB in a more immediate way. As noted by Lambsdorff (2003), corruption includes many different types of behavior. Some of these, like artificial bottlenecks created by public officials, may entail substantial time and effort to be expended by citizens in order to attain public services. Moreover, there may be psychological costs, associated with a general climate of unlawfulness, and similar intangibles.

Based on these considerations the paper hypothesizes that corruption affects SWB not only indirectly, through income, but also directly, through non-material factors. The aim of the paper is to disentangle these potentially distinct effects and to measure their relative size. In

\footnotetext{
${ }^{1}$ See www.icgg.org
} 
addition, the paper estimates the welfare costs of corruption by converting the effects of corruption on SWB into monetary units.

Technically, the basic approach of the paper is to run a cross-national happiness regression with income and corruption as explanatory variables, jointly with an income regression with corruption among the explanatory variables. Given this system of equations, the total effect of corruption on welfare can be decomposed into a direct effect, and an indirect effect via income.

Measuring the welfare costs of corruption requires to translate these effects into monetary units. With respect to marginal changes in corruption, this involves dividing the derivative of happiness with respect to corruption by the derivative with respect to income, thus obtaining the marginal rate of substitution. As regards infra-marginal changes in corruption, a counterpart to the Hicksian compensating surplus will be computed which measures the compensating change in factor costs (rather than income) when corruption levels change and welfare is to remain constant. This measure accommodates the fact that not only less income is required to attain a given welfare level at lower corruption (due to the direct effect), but also that the lower required income level can be produced at lower factor costs (due to the indirect effect).

An intriguing result from our analysis is that the direct welfare effect of corruption is much larger than the indirect effect via income. This suggests that previous studies, which have focused on the income-related effect, have neglected a significant dimension of the problem of corruption. In addition, we find that there is a considerable monetary value to these effects. The changes in corruption in 2001 to 2004, though rather modest on average, are equivalent to capital cost savings (median value) of more than 3 percent of GDP.

Corruption is one of several aspects of the institutional quality prevailing in a country. There have been several previous studies on how happiness is linked to institutional conditions. Frey and Stutzer (2000) showed that happiness in 26 Swiss cantons is positively related to the degree of direct democracy (referenda) and decentralization. In a cross-section study of 27 countries, Bjørnskov (2003) found a sizeable and significant association between happiness and a social capital composite that includes trust, social participation, and the control of corruption. Helliwell (2003) employed panel data from 49 countries to show the existence of substantial well-being benefits from improved quality of governance (a composite measure that includes accountability, effectiveness and stability of government, the rule of law, and control of corruption). While both of these studies confirm the role of per capita income as a predictor of cross-national happiness, they suggest that the effects flowing from the quality of 
institutions may be larger than the effects of economic conditions. However, they disregard the indirect linkage of happiness to institutions via the institutions' effect on income.

In relation to the previous literature, the contribution of the present paper is as follows. First, it focuses explicitly on corruption, rather than on aggregate measures of institutional quality. Second, it offers a unified theoretical framework that allows for a joint investigation of the direct and indirect linkages of happiness to corruption. Third, it provides a monetary valuation of corruption's welfare effects. Finally, the paper not only confirms the importance of controlling corruption, but provides a separation and quantification of direct versus indirect costs of corruption.

The paper is structured as follows. Section 2 presents the methodological framework (general approach, model, welfare measurement, data, empirical approach). Section 3 presents the results (estimation results, welfare effects of corruption, monetary valuation). Section 4 concludes.

\section{Methodological Framework}

\subsection{The General Approach}

Data from happiness surveys are successfully used in a growing literature in economics. In these studies, the emphasis may be on identifying economic determinants of happiness or on using the 'life satisfaction approach' (Frey et al. 2004) as a methodological device for the valuation of public goods (or bads). ${ }^{2}$

In happiness surveys, people are asked to state their degree of happiness or satisfaction with life, for instance "very happy", "quite happy ", "not too happy" etc. In order to be useful for statistical work, the data elicited in this way needs to satisfy certain requirements. Especially, a basic condition for using happiness data as empirical approximations to individual utility is that they be at least ordinal in character and satisfy usual quality standards.

Whether happiness measures meet these conditions has been widely assessed in decades of validation research (see, e.g., Frey and Stutzer 2002). In these studies measures of happiness

\footnotetext{
${ }^{2}$ An early study of the economics of happiness is Easterlin (1974). Later contributions examine the relationship between income distribution and self-rated happiness (Morawetz et al. 1977) and between unemployment and happiness (Clark and Oswald 1994, Winkelmann and Winkelmann 1998). Di Tella et al. (2001) use data from happiness surveys to estimate the trade-off between inflation and unemployment in the framework of a macroeconomic social welfare function. The 'life satisfaction approach' as a valuation technique has been applied to air pollution (Welsch 2002, 2006), aircraft noise (van Praag and Baarsma 2005), climate (Rehdanz and Maddison 2005), terrorism (Frey et al. 2004) and fear of crime (Moore 2006). In this literature, as in the present paper, the terms happiness, life satisfaction, and subjective well-being are used interchangeably. To economists the terminology "experienced utility" may sound more familiar, see Kahnemann et al. (1997).
} 
are generally found to have a high scientific standard in terms of internal consistency, reliability and validity, and a high degree of stability over time (Diener et al. 1999). Different happiness measures correlate well with each other and, according to factor analyses, represent a single unitary construct. Happiness responses are correlated with physical reactions that can be thought of as describing true, internal happiness: People reporting to be happy tend to smile more and show lower levels of stress responses (heart rate, blood pressure). They are more frequently described by others as being happy and they are less likely to commit suicide. In addition to these properties, using happiness data for welfare analysis requires to presume some sort of cardinality. While psychologists and sociologists usually interpret happiness scores as cardinal, economists are inclined to be skeptical about this claim. However, this may be less problematic at a practical level than at a theoretical level (Kahneman 1999), and recent analysis has produced evidence that assuming ordinality or cardinality of happiness scores has little effect on empirical results (Di Tella et al. 2001, Ferrer-i-Carbonell and Frijters 2004). In what follows, we therefore assume that cardinal numbers can be assigned to the verbal happiness categories used in survey questions, yielding an interval-scale measurable variable. As a consequence, we can compute average happiness, and this has methodological advantages, as will be seen immediately.

In specifying a happiness function, there are basically two varieties: a function with individual happiness (micro approach) or a function with aggregate (average) happiness as the dependent variable (macro approach). The micro approach does not require to cardinalize happiness scores (since estimators for ordered variables can be used), but it requires to control for heterogeneity in the individuals' characteristics. As far as socio-demographic and socioeconomic characteristics are concerned, these are usually available in the survey data. In addition, however, there is unobserved heterogeneity across individuals (especially with respect to personality traits). This may affect results substantially (Bertrand and Mullainathan 2001, Ravallion and Lokshin 2001, Ferrer-i-Carbonnell and Frijters 2004) and should be controlled for, if possible. In this regard, the macro approach has an advantage since - if based on representative surveys - unobserved heterogeneity at the micro level can be expected to even out. $^{3}$

Below, we will therefore follow the macro approach, using average happiness by country from representative surveys as the dependent variable in the happiness regression. Cross-

\footnotetext{
${ }^{3}$ An alternative way of dealing with unobserved micro-heterogeneity is based on surveys in which a constant set of individuals is surveyed over time. This allows to use dummy variables for each individual as controls. The problem with this approach is that a fixed set of survey respondents will not remain representative across time.
} 
national heterogeneity will be captured by controls that reflect major cultural, demographic and institutional circumstances. Explanatory variables of interest are per capita income and levels of corruption. The partial derivatives with respect to these explanatory variables can be interpreted as the marginal utility of income and the marginal disutility of corruption, respectively. Their ratio yields the marginal rate of substitution between income and corruption, that is, the marginal monetary value of a change in corruption levels. ${ }^{4}$ Moreover, because the indifference curve over income and corruption is estimated directly, the relevant welfare measures (compensating surplus, equivalent surplus) can be computed even for inframarginal changes in corruption levels.

\subsection{The Model}

The model is designed to capture the material and non-material effects of corruption on SWB, as hypothesized in the Introduction. The model consists of two equations, the happiness equation and the income equation.

The happiness equation accounts for previous findings (see Diener et al. 1999, Frey and Stutzer 2002) saying that happiness is influenced by material, social, and cultural factors. ${ }^{5}$ While the relevant material factor is per capita income and the social factor of interest is corruption, cultural differences across countries are captured by a variable referred to as "rationality", that is, the prevalence of scientific and rational attitudes. The rationality variable differentiates more modern from more traditional societies and provides an effective control to account for culture-specific heterogeneity (Welsch 2003). Another source of cross-national heterogeneity may be the age structure. ${ }^{6}$ We therefore include the median age as an additional control.

The happiness equation can be written as follows:

$$
v=f(y, c, z)
$$

where $v=$ average happiness in a country, $y=$ per capita income, $c=$ corruption measure, $z=$ vector of control variables (rationality, median age). The partial derivative with respect to $y$ is expected to be positive, while the partial derivative with respect to $c$ is expected to be negative. Since the socio-emotional support offered by traditional spiritual institutions has been found to enhance happiness (Veenhoven 1995) and may be lacking in more rationalist

\footnotetext{
${ }^{4}$ Note that the marginal rate of substitution is an ordinal concept, i.e., it is invariant with respect to the cardinalization of utility (happiness) as long as alternative cardinalizations are monotonically increasing transformations of each other.

${ }^{5}$ Since we follow the macro approach (using data on average happiness from representative surveys), personal and demographic variables (age, gender, marital status etc.) play no role in this model.

${ }^{6}$ Age is an important predictor of individual happiness (see, e.g., Helliwell 2003).
} 
environments, the derivative with respect to rationality is expected to be negative. Consistent with previous literature, the derivative with respect to age is likely to be negative over much of the domain (see, e.g., Helliwell 2003).

The income equation is a standard per capita production function familiar from the economics of growth (see, e.g., Hall and Jones 1999, Senhadji 2000), extended to account for corruption (Welsch 2004):

$$
y=g(k, h, c)
$$

where $k=$ physical capital per capita, $h=$ human capital per capita. The material input is thus physical capital. Its productivity is assumed to be influenced by human capital on the one hand and corruption on the other. ${ }^{7}$ The partial derivatives with respect to $k$ and $h$ are expected to be positive, while the partial derivative with respect to $c$ is expected to be negative.

By substituting (2) into (1) we obtain

$$
v=f(g(k, h, c), c, z)
$$

as the reduced form of the model.

\subsection{Welfare Measurement}

This subsection presents the welfare measures to be employed below for evaluating marginal and infra-marginal changes in corruption.

Taking average happiness prevailing in a country as a measure of welfare, the marginal welfare effect (MWE) of corruption can be stated as follows:

$$
M W E:=\frac{d v}{d c}=\frac{\partial f}{\partial y} \frac{\partial g}{\partial c}+\frac{\partial f}{\partial c}
$$

In this formulation, $d v / d c$ represents the total, $(\partial / \partial y)(\partial g / \partial c)$ the indirect and $\partial / \partial c$ the direct marginal welfare effect of corruption.

The marginal welfare effects of corruption can be converted into monetary units by dividing by the marginal welfare effect of income, $\partial f / \partial y$. This yields the monetized marginal welfare effect (MMWE) of corruption:

\footnotetext{
${ }^{7}$ The influence of corruption on capital productivity has been studied by Lambsdorff (2003). Consistent with the above framework, he established a negative impact.
} 


$$
M M W E:=\frac{d v / d c}{\partial f / \partial y}=\partial g / \partial c+\frac{\partial f / \partial c}{\partial f / \partial y}
$$

The MMWE as defined above thus consists of the marginal product of corruption $(\partial \mathrm{g} / \partial \mathrm{c})$ and the marginal rate of substitution (MRS) of income for corruption $(\partial \mathrm{f} / \partial \mathrm{c} / \partial \mathrm{f} / \partial \mathrm{y})$, both expected to be negative.

As stated in subsection 2.1, an advantage of the life satisfaction approach is that it permits to value not only marginal but also infra-marginal changes in the level of public goods or bads. The welfare measures to be used in the empirical part of the paper will be logically similar to the compensating surplus (CS) associated with a change in public good supply. The CS is the amount by which the expenditure on private goods - or equivalently, income - can be reduced when public goods supply increases by a given amount and welfare is to remain unchanged.

A difficulty with the CS or similar measures in the present case is that income available for expenditure is itself affected by the public good (bad) in question, an effect unaccounted for by CS. To accommodate this problem, an analogue measure will be defined which follows the same general logic as the CS but captures both effects of corruption in a comprehensive way. It relies on the circumstance that income is produced by means of capital, and measures the overall effect of reduced corruption in terms of the amount by which the expenditure on capital can be reduced when corruption drops by a given amount and welfare is to remain unchanged.

Formally, let the (conditional) capital expenditure function be defined as follows:

$$
e(v, w ; c):=\min \{w \cdot k: f(g(k, h, c), c, z)=v\}
$$

where $w$ denotes the remuneration rate of capital. ${ }^{8}$ The capital expenditure function gives the capital cost to be expended to attain a predefined welfare level $v$, given $c$ and $w$ (as well as $h$ and $z$ ). Given our assumptions on the partial derivatives of $f($.$) and g($.$) , the capital cost will be$ higher (at given $w$ and $v$ ) the higher is the level of corruption.

When corruption changes from $c_{o}$ to $c_{1}$, the capital cost saved (CCS) at constant welfare $v_{0}$ is:

$$
C C S:=e\left(v_{0}, w_{0} ; c_{0}\right)-e\left(v_{0}, w_{0} ; c_{1}\right)
$$

\footnotetext{
${ }^{8}$ For simplicity, the notation $\mathrm{e}(\mathrm{v}, \mathrm{w} ; \mathrm{c})$ omits the variables $\mathrm{h}$ and the controls.
} 
where the subscript " 0 " refers to the initial situation and the subscript " 1 " to the final situation. CCS is positive when corruption drops and negative when corruption increases. ${ }^{9}$

The actual way of computing CCS proceeds according to the following set of equations:

$$
\begin{aligned}
& C C S=w_{0} k_{0}-w_{0} k_{1}, \\
& v_{0} \equiv f\left(g\left(k_{0}, h_{0}, c_{0}\right), c_{0}, z_{0}\right)=f\left(g\left(k_{1}, h_{0}, c_{1}\right), c_{1}, z_{0}\right), \\
& w_{0}=g_{k}\left(k_{0}, h_{0}, c_{0}\right) .
\end{aligned}
$$

Equation (7a) states that CCS is the difference between the actual capital cost and the hypothetical capital cost at altered corruption and constant welfare. (7b) implicitly determines $k_{1}$, the (hypothetical) capital input required to maintain welfare $v_{0}$ when corruption changes from $c_{0}$ to $c_{1}$. (7c) determines the remuneration rate (price) of capital, where $g_{k}:=\partial g / \partial k$ denotes the marginal product of capital.

Below, CCS will be employed to evaluate the changes in corruption levels that have occurred from 2001 to 2004 .

\subsection{Data}

Our basic data set comprises data for 146 countries around the turn of the millenium. Since not all required variables are available for all countries, the number of countries actually included in the empirical analysis is smaller (see below).

An overview of the data and how they relate to the theoretical variables of the preceding subsections is provided in Table 1.

\footnotetext{
${ }^{9}$ Note that the expenditure function could be extended to comprise more than just one production input, capital. The capital cost savings would then generalize to "factor cost savings". In this paper we deliberately treat labor
} 
Table 1: Data

\begin{tabular}{|c|c|c|c|c|}
\hline $\begin{array}{l}\text { Theoretical } \\
\text { variable }\end{array}$ & $\begin{array}{l}\text { Empirical } \\
\text { variable }\end{array}$ & Description & Unit & Source \\
\hline $\mathrm{V}$ & HAPPY & $\begin{array}{l}\text { Average happiness by country } \\
\text { (welfare measure) }\end{array}$ & {$[1,4]$} & Veenhoven (2005) \\
\hline $\mathrm{c}$ & CORR & $\begin{array}{l}\text { Average perceived corruption } \\
\text { level }\end{array}$ & {$[0,10]$} & $\begin{array}{l}\text { Transparency } \\
\text { International (2005) } \\
\end{array}$ \\
\hline $\mathrm{y}$ & GDPPC & $\begin{array}{l}\text { Gross Domestic Product per } \\
\text { capita }\end{array}$ & PPP\$ & $\begin{array}{l}\text { United Nations } \\
(2003)\end{array}$ \\
\hline $\mathrm{k}$ & CAPPC & Physical capital per capita & $1000 \$$ & $\begin{array}{l}\text { Hall and Jones } \\
\text { (1999) }\end{array}$ \\
\hline h & RESEARCH & $\begin{array}{l}\text { Scientists+engineers per } \\
\text { population }\end{array}$ & persons per million & UNESCO (2005) \\
\hline $\mathrm{Z}$ & RESEARCH & $\begin{array}{l}\text { Scientists+engineers per } \\
\text { population }\end{array}$ & persons per million & UNESCO (2005) \\
\hline $\mathrm{Z}$ & AGE & Median age & years & $\begin{array}{l}\text { United Nations } \\
(2004)\end{array}$ \\
\hline $\mathrm{Z}$ & GOVEFF & Government effectiveness & standardized score & World Bank (2005) \\
\hline $\mathrm{Z}$ & LAW & Rule of law & standardized score & World Bank (2005) \\
\hline
\end{tabular}

The variable HAPPY (average self-reported happiness) comes from the World Database of Happiness (Veenhoven 2005, question type 111B). The categories and their numerical coding are as follows: not at all happy $=1$, not too happy $=2$, quite happy $=3$, very happy $=4$. The data refer to the closest year to 2001 available within the period $1998-2003 .^{10}$ The national averages range from 2.09 to 3.58 .

The variable CORR is Transparency International's Corruption Perceptions Index 2001. It is drawn together from several surveys on the perceptions of corruption by business people and country analysts. Including a country requires that at least three sources are availble, resulting in reliable assessments. The index is expressed on a 10-point numerical scale. The data in our sample ranges from 0.1 (very clean) to 9.6 (very corrupt). ${ }^{11}$

The variables GDPPC and CAPPC are of a more familiar nature. GDPPC comes from the United Nation's Human Development Report. The variable accounts for purchasing power parity. CAPPC comes from the database of Hall and Jones (1999). ${ }^{12}$ RESEARCH comes from UNESCO's Institute for Statistics. ${ }^{13}$ AGE, GOVEFF and LAW are control variables to be employed in the happiness regression. Governmental effectiveness is an index that measures the quality of public service provision, the quality of the bureaucracy, the competence of civil

\footnotetext{
input as fixed.

${ }^{10}$ Countries for which no data is available within 1998-2003 are disregarded.

11 The original data actually indicates absence of corruption, that is, 10 indicates a very clean and 0 a very corrupt country. In the present paper the scaling has been reversed such that 0 refers to the minimum and 10 to the maximum of corruption.

${ }^{12}$ See http://emlab.berkeley.edu/users/chad/HallJones400.asc.

${ }^{13}$ Note that this variable plays a twin role: In the happiness equation it serves as a control that proxies the degree of rationality (modernity) of a society, whereas in the income equation it represents the human capital variable.
} 
servants, the independence of the civil service from political pressure, and the credibility of the government's commitment to policies. The rule of law index is designed to measure the extent to which agents have confidence in and abide by the rules of society and includes the incidence of crime, the effectiveness and predictability of the judiciary, and the enforceability of contracts. Both, governmental effectiveness and the rule of law are broader measures of institutional quality and social capital. They will be included as additional covariates to test model specification and whether or not results concerning corruption come from spurious correlations.

The summary statistics and the countries included in the sample are given in Appendix A.

\subsection{Empirical Approach}

The happiness and income equations from subsection 2.2 will be specified as Cobb-Douglas functions. With respect to the income equation, this specification is consistent with the finding of Lambsdorff (2003) that corruption has an effect on capital productivity (which would be prevented by a linear specification). Moreover, the Cobb-Douglas function is the standard specification in growth economics. The Cobb-Douglas form for happiness avoids, in particular, an unrealistic linear relationship between corruption and happiness. ${ }^{14}$

Taking logarithms, the core estimating equations can be written as follows (where i denotes the countries and $\mathrm{e}_{1 \mathrm{i}}$ and $\mathrm{e}_{2 \mathrm{i}}$ are error terms):

$$
\begin{aligned}
\log \left(\text { HAPPY }_{\mathrm{i}}\right)= & \mathrm{a}_{0}+\mathrm{a}_{1} \log \left(\mathrm{GDPPC}_{\mathrm{i}}\right)+\mathrm{a}_{2} \log \left(\mathrm{CORR}_{\mathrm{i}}\right)+\mathrm{a}_{3} \log \left(\mathrm{RESEARCH}_{\mathrm{i}}\right)+ \\
& \mathrm{a}_{4} \log \left(\mathrm{AGE}_{\mathrm{i}}\right)+\mathrm{e}_{1 \mathrm{i}} \\
\log \left(\mathrm{GDPPC}_{\mathrm{i}}\right)= & \mathrm{b}_{0}+\mathrm{b}_{1} \log \left(\mathrm{CAPPC}_{\mathrm{i}}\right)+\mathrm{b}_{2} \log \left(\mathrm{RESEARCH}_{\mathrm{i}}\right)+\mathrm{b}_{3} \log \left(\mathrm{CORR}_{\mathrm{i}}\right)+\mathrm{e}_{2 \mathrm{i}}
\end{aligned}
$$

In addition to these core specifications, we estimated versions of the happiness equation (8) in which government effectiveness and the rule of law are included as additional controls.

The equations (8) and (9) will be estimated as a system. It should be noted that this system of equations is not an interdependent one, since income is assumed to affect happiness, but not the other way around. With such a recursive system it is appropriate to use the method of seemingly unrelated regressions (SUR), which is equivalent to Maximum Likelihood estimation in the present circumstances. ${ }^{15}$ In contrast to Ordinary Least Squares (OLS), SUR

\footnotetext{
${ }^{14}$ Though unrealistic, we tested linear versions of the happiness equation and found the negative and significant linkage between happiness and corruption confirmed.

${ }^{15}$ For the model specified in equations (8) and (9) the matrix of coefficients of the endogenous variables is triangular, implying that its determinant is 1 . Thus the Jacobian term in the loglikelihood function for the system
} 
accounts for heteroskedasticity and correlation of errors across equations. Similar to OLS, it does not require to assume normality of residuals.

With respect to the happiness equation (8), it is clear that correlations do not establish causation. It may be that happier societies hold lower levels of corruption. ${ }^{16}$ To control for the endogeneity arising in such a scenario, instrumental variable techniques would be appropriate. However, this requires that there are valid instrumental variables that are highly correlated with corruption but not directly related to happiness. It is not clear what instruments might serve this purpose. Therefore, the issue of endogeneity of corruption must be disregarded in what follows.

With respect to the income equation, the issue arises whether to estimate it in differences, rather than levels. In this regard, it should be noted that our inference builds on cross-sectional variation in corruption. As the year-to-year variation in institutional factors, such as corruption, is typically small, differencing would eliminate much of the required variation from which to draw inference. Similarly, the growth rate of GDP usually varies much more than does the growth rate of capital (both physical and human); thus the link between GDP growth and input growth is likely to be very weak. For these and related reasons, levels estimation has gained considerable popularity in macroeconomics (see, e.g. Hall and Jones 1999, Senhadji 2000). In addition, time series data for capital are unavailable for most countries. For these reasons the income equation will be estimated in levels.

\section{Results}

\subsection{Estimation Results}

Table 2 presents the SUR estimates of the model of subsection 2.5. It can be seen from the adjusted $\mathrm{R}^{2}$ that the happiness regression is able to explain about 65 percent of the crossnational variation in happiness. Not surprisingly, this is an explanatory power greater than that usually obtained in micro-regressions of happiness (typically below 30 percent), since the between-country macro variation in happiness is much smaller than the within-country micro variation. With respect to per capita income, the model explains about 85 percent of the variation. Though the income equation (production function) includes only three explanatory variables (physical and human capital per person, level of corruption), this is also not

(8), (9) vanishes, and the loglikelihood function has the same form as the loglikelihood function for a set of linear seemingly unrelated regressions (Davidson and McKinnon 1993, 644-645).

${ }^{16}$ I owe this observation to a referee. 
surprising. Comparable level estimates of per capita income with physical and human capital alone yield $\mathrm{R}^{2}$ values that range up to 99 percent for some of the OECD countries and rarely fall below 40 percent for developing countries (Senhadji 2000). ${ }^{17}$

The coefficients all have the expected sign and are significant. The results thus suggest that social welfare, as captured by average happiness, is positively and significantly linked to per capita income and negatively and significantly to corruption. Per capita income, in turn, is also negatively and significantly linked to corruption. ${ }^{18}$ In quantitative terms, the elasticity of happiness with respect to income is relatively low, which is a common finding in empirical happiness research (see, e.g., Frey et al 2004). The production elasticity of capital is quite close to the usual consensus value of $1 / 3$ derived from income shares.

Table 2: Estimation Results

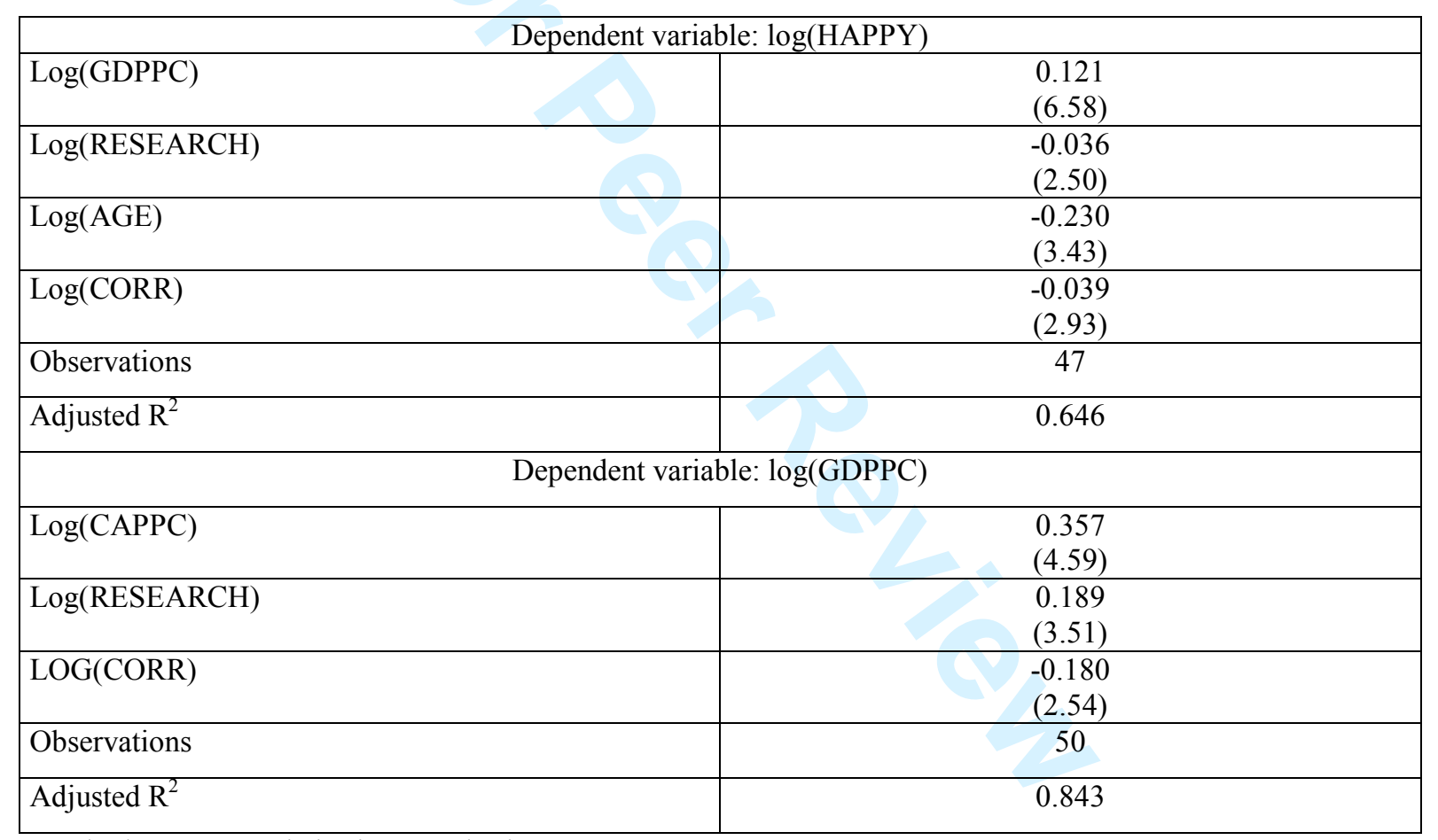

Method: SUR; t-statistics in parenthesis

In addition to these core estimates, we tested model versions in which the happiness equation is augmented by additional indicators of institutional quality and social capital, namely government effectiveness and the rule of law (see Appendix B). Given that these additional controls take the form of standardized scores (z-scores), some of their values are negative by

\footnotetext{
${ }^{17}$ Consistent with the discussion at the end of subsection 2.5, the corresponding estimates in first differences yield much smaller coefficients of determination (Senhadji 2000).

${ }^{18}$ The marginal significance level of corruption in the income equation is 1.29 percent, whereas it is 0.43 in the happiness equation.
} 
construction. They are therefore included as levels rather than logarithms. However, additional regressions include rescaled, strictly positive versions of these indicators in logarithmic form (see the note in Appendix B). Inclusion of these institutional controls, in whatever way, left corruption negative and significant, and raised rather than reduced the absolute magnitude of the coefficient on corruption. The additional institutional indicators themselves turn out to be insignificant and/or tend to have the wrong sign. Among all institutional variables considered, corruption is the only one that displays a robust and significant negative linkage to happiness. It is thus to be conjectured that much of the detrimental effect to be expected from unlawfulness and poor public services may be related to corruption. ${ }^{19}$

Overall, these estimates support the basic hypothesis that corruption has both indirect (income-related) and direct (income-independent) effects on welfare. The next subsection addresses the size of these partial effects as well as of the total effect, using the coefficients from the core estimates reported in Table 2.

\subsection{Marginal Welfare Effects}

Given the estimates presented above, we are able to compute the direct, indirect and total marginal effects of corruption on welfare, as defined in subsection 2.3. More specifically, we compute the direct, indirect and total derivatives of happiness with respect to corruption and their monetary equivalents.

We first note that due to the specification given in subsection 2.5, the direct marginal effect can be written as $\mathrm{a}_{2} *\left(\mathrm{HAPPY}_{\mathrm{i}} / \mathrm{CORR}_{\mathrm{i}}\right)$ whereas the indirect effect can be written as $a_{1} * b_{3} *\left(H_{A P P Y} / C_{i} O R R_{i}\right)$ This implies that for any single country the direct and indirect effects are proportional to $\mathrm{a}_{2}=-0.039$ and $\mathrm{a}_{1} * \mathrm{~b}_{3}=0.121 *-0.180=-0.022$, respectively. We thus find that the direct effect is almost 1.8 times larger than the indirect effect.

Table 3 presents numerical values of the marginal effects of corruption in terms of percentiles of the total effect. The median value $\left(50^{\text {th }}\right.$ percentile) of the total effect is -0.033 . This means that in 50 percent of the cases an increase in corruption by 1 point (on the 10-point scale) reduces happiness by more than 0.033 (on the 4-point happiness scale). There is considerable dispersion in the total effect, as indicated by the $10^{\text {th }}$ and $90^{\text {th }}$ percentile.

\footnotetext{
${ }^{19}$ With respect to transition economies, May et al. (2002) report that corruption significantly enhances unofficial activity, whereas government effectiveness and the rule of law display no such influence.
} 
The monetary equivalents are quite substantial. The median value for the total effect is about $\$ 900$ per capita per year. The indirect effect amounts to more than $\$ 300$ and the direct effect to almost $\$ 600$ at the median.

Table 3: Marginal Effects of Corruption

\begin{tabular}{|l|c|c|c|c|c|c|}
\hline & \multicolumn{3}{|c|}{ Marginal welfare effect } & \multicolumn{3}{c|}{ Monetized marginal welfare effect } \\
\hline percentile & total & indirect & direct & total & indirect & direct \\
\hline $10^{\text {th }}$ & -0.021 & -0.007 & -0.014 & -127 & -45 & -81 \\
\hline $25^{\text {th }}$ & -0.025 & -0.009 & -0.016 & -310 & -111 & -199 \\
\hline $50^{\text {th }}$ & -0.033 & -0.012 & -0.021 & -899 & -322 & -577 \\
\hline $75^{\text {th }}$ & -0.069 & -0.025 & -0.043 & -4098 & -1468 & -2629 \\
\hline $90^{\text {th }}$ & -0.188 & -0.068 & -0.111 & -13085 & -4689 & -8396 \\
\hline
\end{tabular}

Note: The percentile values for direct and indirect effects do not necessarily add up to the percentile values for the total effect, because they may correspond to different countries.

When considering these marginal effects, it should be clear, however, that "marginal change of corruption" in fact refers to a change by 1 point on a 10-point scale. In practice, this amounts to a relatively strong change, at least in the intermediate term. The next subsection will therefore address the monetary valuation of those changes in corruption which actually occurred in the recent past.

\subsection{Infra-marginal Welfare Effects}

In this subsection we present the valuation of the changes in corruption that have taken place in 2001-2004. These changes range from a decrease (improvement) by 1.1 on the 10-point scale (Bangladesh) to an increase (deterioration) by 1.3 points (Namibia), but most of the changes were of a more moderate magnitude, as shown in the histogram in Figure 1. Out of the 87 countries for which observations are available, 41 countries experienced an improvement and 37 a deterioration. In 9 countries the corruption level was constant. 
Figure 1: Changes in Corruption 2001-2004

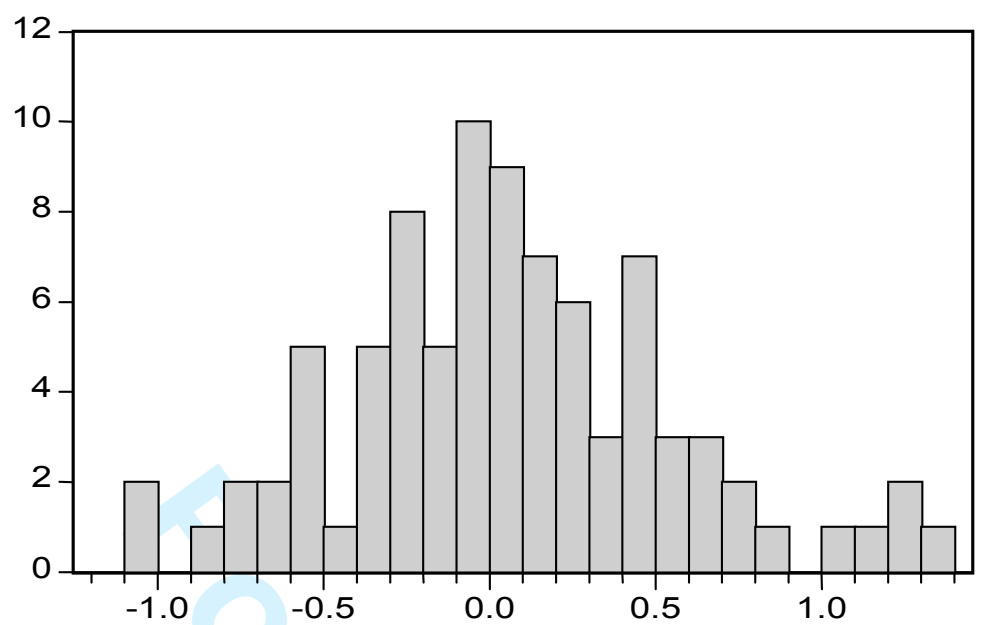

Table 4 shows the economic value of these changes for the countries that improved and those that deteriorated, respectively. The measure shown is the capital cost savings at constant welfare defined in subsection 2.3. Cost savings are expressed as fractions of GDP in 2001. In the countries that succeeded in reducing corruption, the median value of compensating capital cost savings (CCS) is 3.6 percent of GDP. The $10^{\text {th }}$ and $90^{\text {th }}$ percentiles indicate a considerable dispersion of these values. Similar results apply to the countries in which corruption increased. The median value of CCS in these countries is -3.5 percent of GDP.

Table 4: Capital Cost Savings due to Changes in Corruption 2001-2004

\begin{tabular}{|l|c|c|}
\hline percentile & decrease in corruption $(\mathrm{n}=41)$ & increase in corruption $(\mathrm{n}=37)$ \\
\hline $10^{\text {th }}$ & 0.007 & -0.008 \\
\hline $25^{\text {th }}$ & 0.015 & -0.021 \\
\hline $50^{\text {th }}$ & 0.036 & -0.035 \\
\hline $75^{\text {th }}$ & 0.085 & -0.055 \\
\hline $90^{\text {th }}$ & 0.129 & -0.150 \\
\hline
\end{tabular}

Note: Entries are the capital cost savings at constant welfare (see equ. (7)) as fractions of GDP in 2001.

It can thus be stated that the changes in corruption 2001-2004 represent a considerable monetary value. 


\section{Conclusions}

Empirical research has shown that corruption affects a variety of economic indicators, especially GDP per capita. However, as GDP is not a genuine indicator of welfare, it reflects the welfare costs of corruption only in an incomplete way.

Motivated by this shortcoming, the present paper has used self-rated subjective well-being as an empirical approximation to general welfare to explore several channels through which welfare, operationalized in this way, is affected by corruption. It was found that corruption affects cross-national welfare not only indirectly, through GDP, but also directly, due to, e.g., the time and effort required to cope with corrupt behavior, or psychological costs associated with a general climate of unlawfulness. Interestingly, the direct effect - which has not previously been investigated in the corruption literature - was found to be substantially larger than the indirect effect and to imply a considerable welfare loss.

As regards the relatively small size of the indirect effect, it should be noted that this effect is the effect of corruption on income times the effect of income on subjective well-being. As the latter is typically small (see, e.g., Frey et al. 2004), so is the indirect effect of corruption on welfare.

In monetary terms, the changes in corruption in 2001-2004 are equivalent to a change in the stock of physical capital worth more than 3 percent of GDP (median). The welfare costs of corruption, as measured by the monetized effect of corruption on subjective well-being, are thus of a considerable magnitude. 


\section{References}

Bertrand, M., Mullainathan, S. (2002), Do People Mean What They Say? Implications for Subjective Survey Data, American Economic Review 91, 67-72.

Bjørnskov, (2003), The Happy Few: Cross-Country Evidence on Social Capital and Life Satisfaction, Kyklos 56, 3-16.

Clark, A.E., Oswald, A.J., (1994), Unhappiness and Unemployment, Economic Journal 104, 648-659.

Davidson, R., McKinnon, J.G. (1993), Estimation and Inference in Econometrics, New York, Oxford: Oxford University Press.

Diener, E., Suh, E.M., Lucas, R.E., Smith, H.L. (1999), Subjective Well-Being: Three Decades of Progress, Psychological Bulletin 125, 276-302.

Di Tella, R., MacCulloch, R., Oswald, A. (2001), Preferences over Inflation and Unemployment: Evidence from Surveys of Happiness, American Economic Review 91, 335-341.

Di Tella, R., MacCulloch, R., Oswald, A. (2003), The Macroeconomics of Happiness, Review of Economics and Statistics 85, 809-827.

Easterlin, R. (1974), Does Economic Growth Improve the Human Lot? Some Empirical Evidence, in: P.A. David and M.W. Reder (eds.), Nations and Households in Economic Growth: Essays in Honour of Moses Abramovitz, New York, London: Academic Press, 89125.

Ferrer-i-Carbonell A., Frijters, P. (2004), How Important is Methodology for the Estimates of the Determinants of Happiness?, Economic Journal 114, 641-659.

Frey, B.S., Stutzer, A. (2000), Happiness, Economy and Institutions, The Economic Journal 110, 918-938.

Frey, B.S., Stutzer, A. (2002), What Can Economists Learn from Happiness Research?, Journal of Economic Literature XL, 402-435.

Frey, B.S., Luechinger, S., Stutzer, A. (2004), Valuing Public Goods: The Life Satisfaction Approach, CESifo Working Paper No.1158.

Hagerty, M.R., Veenhoven, R. (2003), Wealth and Happiness Revisited: Growing National Income Does Go with Greater Happiness, Social Indicators Research 64, 1-27.

Hall, R., Jones, C. (1999), Why do Some Countries Produce so much more Output per Worker than Others?, Quarterly Journal of Economics 114, 83-116.

Helliwell, J.F. (2003), How's life? Combining individual and national variables to explain subjective well-being, Economic Modelling 20, 331-360.

Kahneman, D. (1999), Objective Happiness, in: D. Kahneman, E. Diener, N. Schwarz (eds.): Well Being: The Foundations of Hedonic Psychology, New York: Russell Sage Foundation.

Kahnemann, D., Wakker, P., Sarin, R. (1997), Back to Bentham? Explorations of Experienced Utility, Quarterly Journal of Economics 112, 375-406. 
Lambsdorff, J.G. (1999), Corruption in Empirical Research, Transparency International Working Paper, www.transparency.org/documents/work-papers.

Lambsdorff, J.G. (2003), How Corruption Affects Productivity, Kyklos 56, 457-474.

May, J.W., Pyle, W., Sommers, P.M. (2002), Does Governance Explain Unofficial Activity?, Applied Economics Letters 9, 537-539.

Moore, S.C. (2006), The Value of Reducing Fear: An Analysis using the European Social Survey, Applied Economics 38, 115-117.

Morawetz, D. et al. (1977), Income Distribution and Self-Rated Happiness: Some Empirical Evidence, Economic Journal 87, 511-522.

Ravallion, M., Lokshin, M. (2001), Identifying Welfare Effects from Subjective Questions, Economica 68, 335-357.

Rehdanz, K., Maddison, D. (2005), Climate and Happiness, Ecological Economics 52, 111-125.

Senhadji, A. (2000), Sources of Economic Growth: An Extensive Growth Accounting Exercise, IMF Staff Papers 47, 129-157.

Transparency International (2000), TI Source Book 2000, www.transparency.org/sourcebook.

Transparency International (2005), Corruption Perceptions Index, www.icgg.org

UNESCO (2005), United Nations Economic, Scientific and Cultural Organization, Institute for Statistics, www.uis.unesco.org/ev.php

United Nations (2003), Human Development Report, http://hdr.undp.org/reports/global/2003/

United Nations (2004): World Population Prospects: The 2004 Revision, http://esa.un.org/unpp/

Van Praag, B., Baarsma, B. (2005) Using Happiness Surveys to Value Intangibles: The Case of Airport Noise, Economic Journal 52, 111-125.

Veenhoven, R. (1995), The Cross-National Pattern of Happiness: Test of Predictions Implied in Three Theories of Happiness, Social Indicators Research 34, 33-68.

Veenhoven, R. (2005), World Database of Happiness, http://www2.eur.nl/fsw/research/happiness.

Welsch, H. (2002), Preferences over Prosperity and Pollution: Environmental Valuation Based on Happiness Surveys, Kyklos 55(4), 473-494.

Welsch, H. (2003), Freedom and Rationality as Predictors of Cross-National Happiness Patterns, Journal of Happiness Studies 4, 295-321.

Welsch, H. (2004), Corruption, Growth and the Environment, Environment and Development Economics 9, 663-693.

Welsch, H. (2006), Environment and Happiness: Valuation of Air Pollution Using Life Satisfaction Data, Ecological Economics, forthcoming.

Winkelmann, L., Winkelmann, R. (1998), Why are the Unemployed so Unhappy?, Economica 65, 1-15.

World Bank (2005), Governance Indicators, http://info.worldbank.org/governance/ govdata2002/index.html 


\section{Appendix A: Data}

Summary statistics:

\begin{tabular}{|c|c|c|c|c|c|}
\hline & HAPPY & CORR & GDPPC & CAPPC & RESEARCH \\
\hline Mean & 2.998194 & 5.367816 & 8674.776 & 27.70546 & 1613.060 \\
\hline Median & 2.980000 & 6.100000 & 4720.000 & 16.31761 & 1258.440 \\
\hline Maximum & 3.580000 & 9.600000 & 36600.00 & 109.0978 & 7110.450 \\
\hline Minimum & 2.090000 & 0.100000 & 520.0000 & 0.330300 & 1.820000 \\
\hline Std. Dev. & 0.312326 & 2.333950 & 9531.697 & 29.62113 & 1610.690 \\
\hline Observations & 72 & 87 & 134 & 93 & 73 \\
\hline & AGE & GOVEFF & LAW & & \\
\hline Mean & 25.69793 & -0.081027 & -0.107671 & & \\
\hline Median & 23.10000 & -0.395000 & -0.415000 & & \\
\hline Maximum & 41.30000 & 2.260000 & 2.030000 & & \\
\hline Minimum & 14.90000 & -1.780000 & -1.790000 & & \\
\hline Observations & 145 & 146 & 146 & & \\
\hline
\end{tabular}

List of countries:

Argentina (v,y); Australia (y); Austria (v,y); Belgium (v,y); Bolivia (v,y); Brazil (y); Bulgaria (v); Canada (v,y); Chile (v,y); China (v,y); Columbia (v,y); Croatia (v); Czech Republik (v,y); Denmark $(\mathrm{v}, \mathrm{y})$; Ecuador $(\mathrm{y})$; El Salvador $(\mathrm{v}, \mathrm{y})$; Estonia $(\mathrm{v})$; Finland $(\mathrm{v}, \mathrm{y})$; France $(\mathrm{v}, \mathrm{y})$; Germany $(\mathrm{v}, \mathrm{y})$; Greece $(\mathrm{v}, \mathrm{y})$; Hungary $(\mathrm{v}, \mathrm{y})$; Iceland $(\mathrm{v}, \mathrm{y})$; Ireland $(\mathrm{v}, \mathrm{y})$; Israel $(\mathrm{v}, \mathrm{y})$; Italy $(\mathrm{v}, \mathrm{y})$; Japan (v,y); Jordan (v,y); Latvia (v); Lithuania (v); Malaysia (y); Mexico (v,y); Moldova (v); Netherlands (v,y); New Zealand (v,y); Nicaragua (y); Norway (y); Panama (y); Peru (v,y); Poland (v,y); Portugal (v,y); Romania (v,y); Russia (v,y); Senegal (y); Slovakia (v); Slovenia (v); Spain (v,y); Sweden (v,y); Switzerland (v,y); Thailand (y); Trinidad \& Tobago (y); Tunisia (y); Turkey (v,y); Uganda (v,y); Ukraine (v); United Kingdom (v,y); United States (v,y); Uruguay (y); Venezuela (v,y);

Note: The letters $\mathrm{v}$ and $\mathrm{y}$ in parentheses indicate that the country is included in the happiness equation or/and the income equation, respectively. 
Appendix B: Robustness Tests

\begin{tabular}{|c|c|c|c|c|c|c|}
\hline \multicolumn{7}{|c|}{ Dependent Variable: $\log ($ HAPPY) } \\
\hline $\log (\mathrm{GDPPC})$ & $\begin{array}{c}0.122 \\
(5.11)\end{array}$ & $\begin{array}{c}0.134 \\
(5.90)\end{array}$ & $\begin{array}{l}0.135 \\
(5.87)\end{array}$ & $\begin{array}{c}0.142 \\
(6.61)\end{array}$ & $\begin{array}{l}0.127 \\
(5.55)\end{array}$ & $\begin{array}{r}0.136 \\
(6.25) \\
\end{array}$ \\
\hline Log(RESEARCH) & $\begin{array}{l}-0.036 \\
(2.49)\end{array}$ & $\begin{array}{l}-0.032 \\
(2.30)\end{array}$ & $\begin{array}{l}-0.032 \\
(2.29)\end{array}$ & $\begin{array}{l}-0.030 \\
(2.20)\end{array}$ & $\begin{array}{l}-0.033 \\
(2.43)\end{array}$ & $\begin{array}{l}-0.032 \\
(2.35)\end{array}$ \\
\hline $\log (\mathrm{AGE})$ & $\begin{array}{l}-0.230 \\
(3.42)\end{array}$ & $\begin{array}{l}-0.236 \\
(3.55)\end{array}$ & $\begin{array}{r}-0.233 \\
(3.52)\end{array}$ & $\begin{array}{l}-0.229 \\
(3.54)\end{array}$ & $\begin{array}{l}-0.216 \\
(3.35)\end{array}$ & $\begin{array}{r}-0.213 \\
(3.29)\end{array}$ \\
\hline $\log (\mathrm{CORR})$ & $\begin{array}{l}-0.039 \\
(2.47) \\
\end{array}$ & $\begin{array}{r}-0.046 \\
(3.18) \\
\end{array}$ & $\begin{array}{r}-0.050 \\
(3.15) \\
\end{array}$ & $\begin{array}{r}-0.051 \\
(3.65)\end{array}$ & $\begin{array}{r}-0.046 \\
(2.99) \\
\end{array}$ & $\begin{array}{r}-0.049 \\
(3.57) \\
\end{array}$ \\
\hline GOVEFF & $\begin{array}{l}-0.001 \\
(0.07)\end{array}$ & & & & $\begin{array}{l}0.081 \\
(1.90)\end{array}$ & \\
\hline $\log (\mathrm{GOVEFF})^{*}$ & & $\begin{array}{l}-0.055 \\
(1.08)\end{array}$ & & & & $\begin{array}{l}0.129 \\
(1.28)\end{array}$ \\
\hline LAW & & & $\begin{array}{c}-0.026 \\
(1.18)\end{array}$ & & $\begin{array}{c}-0.096 \\
(2.24)\end{array}$ & \\
\hline $\log (\mathrm{LAW})^{*}$ & & & & $\begin{array}{c}-0.095 \\
(1.99)\end{array}$ & & $\begin{array}{l}-0.201 \\
(2.09)\end{array}$ \\
\hline Observations & 47 & 47 & 47 & 47 & 47 & 47 \\
\hline Adj. R2 & 0.637 & 0.642 & 0.644 & 0.659 & 0.662 & 0.664 \\
\hline \multicolumn{7}{|c|}{ Dependent Variable: $\log ($ GDPPC $)$} \\
\hline $\log (\mathrm{CAPPC})$ & $\begin{array}{l}0.357 \\
(4.59) \\
\end{array}$ & $\begin{array}{l}0.357 \\
(4.60)\end{array}$ & $\begin{array}{r}0.356 \\
(4.59)\end{array}$ & $\begin{array}{l}0.357 \\
(4.60) \\
\end{array}$ & $\begin{array}{l}0.355 \\
(4.57) \\
\end{array}$ & $\begin{array}{r}0.355 \\
(4.57) \\
\end{array}$ \\
\hline $\log (\mathrm{RESEARCH})$ & $\begin{array}{l}0.189 \\
(3.50)\end{array}$ & $\begin{array}{l}0.188 \\
(3.50)\end{array}$ & $\begin{array}{c}0.189 \\
(3.51)\end{array}$ & $\begin{array}{l}0.188 \\
(3.51)\end{array}$ & $\begin{array}{l}0.189 \\
(3.52)\end{array}$ & $\begin{array}{l}0.189 \\
(3.54)\end{array}$ \\
\hline LOG(CORR) & $\begin{array}{l}-0.180 \\
(2.54)\end{array}$ & $\begin{array}{l}-0.181 \\
(2.55)\end{array}$ & $\begin{array}{l}-0.181 \\
(2.55)\end{array}$ & $\begin{array}{l}-0.181 \\
(2.56)\end{array}$ & $\begin{array}{l}-0.180 \\
(2.54)\end{array}$ & $\begin{array}{l}-0.181 \\
(2.55)\end{array}$ \\
\hline Observations & 50 & 50 & 50 & 50 & 50 & 50 \\
\hline Adj. R2 & 0.843 & 0.843 & 0.843 & 0.843 & 0.843 & 0.843 \\
\hline
\end{tabular}

* The variables GOVEFF and LAW are standardized scores (z-scores), some of which have negative values by construction. To be able to compute logarithms to be included in some of the regressions reported above, they have been rescaled such that the smallest value equals 1 and the largest value equals 10 . 